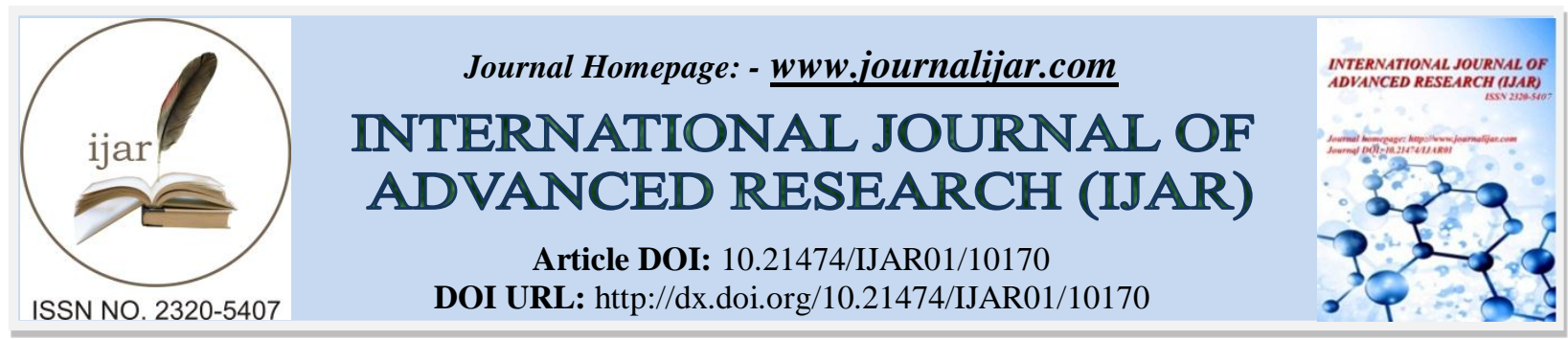

RESEARCH ARTICLE

\title{
THE PACKS OF PICTURE-BASED LEARNING SOURCES OF THE BODY IMMUNITY SYSTEM MATERIAL PROCESS FOR IMPROVING STUDENTS LEARNING OUTCOMES AND HIGHER- ORDER THINKING SKILLS
}

Endang Widyaningrum, Sutarto, Jekti Prihatin and Indrawati

Magister of Science Education, University of Jember, Indonesia Kalimantan Street No 37 Jember 68118.

\section{Manuscript Info}

.1.........................

Manuscript History

Received: 05 October 2019

Final Accepted: 07 November 2019

Published: December 2019

Key words:-

Learning Source Package, Process

Picture, And Higher-Order Thinking Skill

\section{Abstract}

Biology learning in Indonesia needs a learning source which can fulfill the students' needs nowadays, the learning source which improves the learning results and high order thinking ability of the students. The package of picture based learning source is a form of sources which contain contextual materials for decreasing the conceptual mistake, the writing mistake, or the language mistake, and present the pictures containing difference process or stages from the learning source in general. This research aims to know the improvement of learning result and high order thinking ability of the students through the package of process picture based learning resource on immunity material. The design of this research was by using the score of pre-test and post-test and the test of higher order thinking skills (HOTS) at three different Senior High Schools. Data obtained were then analyzed by using Recognition method to know the category of students' higher order thinking skill. The research results at three schools experience improvement in each meeting of the learning and reach good criteria with the average score 80.1 (School A), 84,0 (School B), and 83,7 (School C).

Copy Right, IJAR, 2019,. All rights reserved.

\section{Introduction:-}

The good and suitable learning implementation with the education curriculum in Indonesia is learning that is able to create an active, critical, analytical, and creative atmosphere in problem solving through the student cognitive development. Thus, in order to meet the learning objectives of the educational curriculum, all fields of study in the school including Biology subjects need to be directed to the latest learning demands so the learning can be more meaningful. Learning Biology should be conducted through scientific approach In order to obtain interactive, inspiring, active, fun, and challenging learning, as well as providing sufficient space for initiative, creativity, and also independence as students talents, interests, and physical and psychological development ( Ministry of Education and Culture, 2016). Therefore, preliminary knowledge can be obtained from the students experience, the experiences of others that the students know, and other real information as a source of learning.

The learning source is all supporting source in learning activities including support and material systems as the learning environment (Seels \& Richey, 1994). Learning source is the one of information for students and also guidelines of the material that has to be transferred. The learning sources which often used in learning are books, textbooks, student worksheets, and modules (Sa'adah, 2016). One of the criteria for a good learning source is user 
friendly, which means it can be easily understood by the users, which are students who learn and teachers who teach (Hadiyanti, et al., 2013). The existing learning sources are expected to be function and used by the students in supporting the learning process (Morrison, 2004). Therefore, learning sources are good and useful for students, if the learning sources can simplify the comprehension of difficult concepts or material including Biology subjects and students improve learning outcomes and

\section{Higher-Order Thinking Skill (HOTS):}

The learning outcomes value is an indicator that can be used to measure students learning success. The learning outcomes value reflects the outcomes achieved by students. There are three aspects of learning outcomes which are cognitive, psychomotor, and affective aspects (Maisaroh dan Rostrieningsih, 2010). Cognitive process in HigherOrder Thinking Skill (HOTS) involves analysis and synthesis (C4), evaluating (C5), and creating or creativity (C6) (Anderson \& Krathworl, 2001). Higher Order Thinking Skill (HOTS) are thinking skills that combine critical thinking and creative thinking (Zaini, 2015). According to the result of needs analysis questionnaire of Biology teachers of six teachers in six Senior High Schools (SHS), consisted of four public schools and two private schools in Pasuruan Regency, it is known that the majority of Biology teachers have not fully implemented creative learning as the curriculum in Indonesia. There are still many teachers who use printed learning sources, such as books and worksheets, and the minimum use of creative, interesting and unique learning sources, which make it different from learning sources in general. This matter can affect the level of student success in receiving Biology learning.

The students' success factor in learning Biology is tended to be valued from one side that emphasizes cognitive aspects only, so that the students learning outcomes are low especially in Biology materials that require comprehension such as the body immunity system material. Wening (2014) explained that Biology material requires higher-order thinking abilities such as critical, logical, analytical thinking, and sometimes even combinatorial thinking. This matter can be proven from the interview results with six Biology teachers in grade XI of Senior High School in four public schools and two private schools which revealed that the body immunity material is considered as difficult material to be mastered by students. The difficulty is caused by the learned material which tends to be abstract and difficult to imagine, especially in the mechanism of body immunity system. In general, the average value for this material reaches 66.93 or still below the minimum score of 80 , so it needs to be more improved.

The problem related to students difficulties in learning the body immunity system include the minimum use of learning sources by teachers in teaching the material (Anderson, 2001). Learning sources have minimum updated information and have not honed students thinking skills, so they are unable in fostering students learning motivation and have to developed a learning source that is able to meet the students needs, which are the learning sources pack that links all information or concepts of body immunity system material to the environment, source, data, occasion, real events and learning videos that are packed as attractive as possible.

This learning resource needs to be packed in printed form due to many teachers like printed learning sources, which will ease teachers in using it (Sa'adah, 2016). Learning resource packs have to be developed by containing contextual material and arranged as best as possible to reduce concept, writing, and language errors. To minimize these mistakes, the learning source pack is made in more fun and easy way to comprehend through pictures that contain a process or stages that tend to be different with the student handbook in general. The combination of words and pictures will encourage students brains to memorize and delve the meaning in thinking activities, so the goal to improve students higher-order thinking skills can be realized. Therefore, it needs to be compiled a pack of picturebased learning source that contains a series of objects pictures that can visualize a fact or phenomenon with a logical and orderly process or coherent, so it helps to ease the students in comprehending something they learned (Sutarto, et al., 2018). Through the use of process images in this learning source pack, the students will understand the material or the concept of body immunity system faster.

The picture-based Biology learning source pack which is developed can be used as a learning medium in the teaching and learning process which are student-centered learning as the constructivist approach. At the beginning of the learning process which uses the picture-based learning source pack presents problems through pictures of contextual biology events from real life in relation to the concept of the human body immunity system and its implementation in daily life. Giving problems in the beginning of learning can improve students analytical thinking process. The problem solving process will be able to develop students thinking skills (Downing, et al., 2009). In addition, the given problem in the beginning of learning also encourages students to identify, define, and organize 
problems also finding information for their resolution through sources such as text, pictures and others with the goal of being able to solve these problems.

Therefore, to overcome these learning problems, it is necessary to use a picture-based learning source pack for the body immunity system material to improve learning outcomes and students higher-order thinking skills.

\section{Methodology:-}

This research was a quasi experimental design research. The subjects of the research were students of grade XI MIPA at Bangil Al Aziz High School (School A), Bangil Muhammadiyah 2 High School (School B), and Bangil Yadika High School (School C), Pasuruan, Indonesia in academic year of 2018/2019. Research design of learning outcomes used Pretest-Posttest result, while Higher-Order Thinking Skill (HOTS) research design used HOTS test scores. The measurement of learning outcomes and Higher-Order Thinking Skill (HOTS) was conducted in each school based on the test results.

\section{Results:-}

This research aims to find out the improvement in learning outcomes and high-level thinking skills of students through picture-based learning source pack about the body immunity system. The learning outcomes are measured through pretest-posttest result and higher-order thinking skills (HOTS) are measured by the results of the HOTS test score. Pretest-posttest and higher-order thinking skills questions are given in two meetings. Furthermore, HOTS scores are analyzed using a higher-order thinking ability test score. Higher-order thinking skills scores are calculated in the form of value (formula 1), then it is explained based on the categories which can be seen in Table 1, for the average value of higher-order thinking skills from the results of research that has been conducted can be seen in Table 2, the average value of learning outcomes can be seen in Table 3, and the average value of learning outcomes and higher-order thinking skills can be seen in Table 4.

$$
C s=\frac{\text { HOTS Scores }}{\text { Maximum scores }} \times 100
$$

(Shidiq, et al., 2014)

Table 1:- Score categories of higher-order thinking

\begin{tabular}{|c|c|}
\hline The Average of HOTS Indicator Achievement & Category \\
\hline $20 \leq \mathrm{P}<36$ & Bad \\
\hline $36 \leq \mathrm{P}<52$ & Poor \\
\hline $52 \leq \mathrm{P}<68$ & Fair \\
\hline $68 \leq \mathrm{P}<84$ & Good \\
\hline $84 \leq \mathrm{P}<100$ & Excellent \\
\hline
\end{tabular}

Table 2:- Results of Students' Higher-Order Thinking Skills

\begin{tabular}{|c|c|c|c|c|c|}
\hline \multirow{2}{*}{ No. } & \multirow{2}{*}{ Schools } & \multicolumn{4}{|c|}{ Meeting and Category } \\
\cline { 3 - 6 } & & I & Category & II & Category \\
\hline 1. & $\mathrm{~A}(\mathrm{~N}=21)$ & 75.6 & Good & 84.5 & Excellent \\
\hline 2. & $\mathrm{~B}(\mathrm{~N}=28)$ & 82.4 & Good & 85.6 & Excellent \\
\hline 3. & $\mathrm{C}(\mathrm{N}=30)$ & 82.8 & Good & 84.5 & Excellent \\
\hline
\end{tabular}

Table 3:- Average Improvement of Student Learning Outcomes

\begin{tabular}{|l|c|c|c|c|}
\hline \multirow{2}{*}{ Learning Result } & \multirow{2}{*}{ Meeting } & \multicolumn{3}{|c|}{ Schools } \\
\cline { 2 - 5 } & & $\mathbf{A}(\mathbf{N}=\mathbf{2 1})$ & $\mathbf{B}(\mathbf{N}=\mathbf{2 8})$ & $\mathbf{C}$ (N=30) \\
\hline \multirow{2}{*}{ Pretest } & I & 62.6 & 63.3 & 67.0 \\
\cline { 2 - 5 } & II & 64.3 & 64.1 & 68.6 \\
\hline \multirow{2}{*}{ Posttest } & I & 77.7 & 87.0 & 82.7 \\
\cline { 2 - 5 } & II & 89.0 & 87.8 & 84.5 \\
\hline
\end{tabular}


Table 4:- The Average of Learning Outcomes and Students' Higher-Order Thinking Skills

\begin{tabular}{|c|c|c|c|}
\hline & $\begin{array}{c}\text { School A } \\
(\mathbf{N = 2 1})\end{array}$ & $\begin{array}{c}\text { School B } \\
(\mathbf{N = 2 8})\end{array}$ & $\begin{array}{c}\text { School C } \\
(\mathbf{N = 3 0 )}\end{array}$ \\
\hline Pretest & 63.5 & 63.7 & 67.8 \\
\hline Posttest & 83.4 & 87.4 & 83.6 \\
\hline HOTS & 80.1 & 84.0 & 83.7 \\
\hline
\end{tabular}

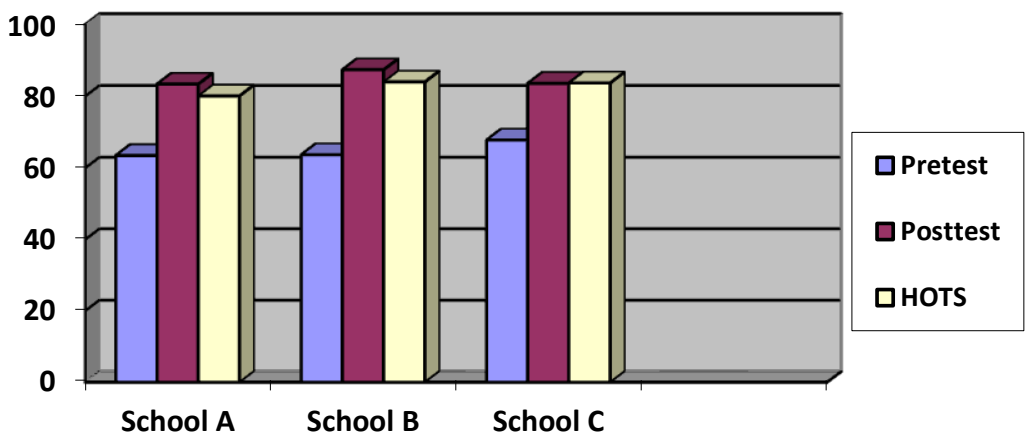

Picture 1:- The Diagram of Learning Outcomes and Students Higher-Order Thinking Skills

Tables 3 and 4 show the average scores of higher-order thinking skills and student pretest-posttest results which are increasing at each learning meeting. The score of higher-order thinking skills in school A is 80.1; school B is 84.0; and school is $\mathrm{C} 83.7$ in the Good category. For the average value of student learning outcomes (pretest-posttest), school A is 73.5; school B is75.6; and school C is 75.7 in the Good category. Furthermore, to measure the implementation activities of higher-order thinking skills in each aspect uses Likert scale of 1 to 5. The criteria for the implementation activity of higher-order thinking skills can be seen in Table 5 and for the frequency score of the implementation activity of higher-order thinking skills are seen in table 6.

Table 5:- The Criteria for the implementation activity of higher-order thinking skills

\begin{tabular}{|c|c|c|}
\hline No & Percentage (\%) & Criteria \\
\hline 1 & $20 \leq \mathrm{x}<36$ & Very Low \\
\hline 2 & $36 \leq \mathrm{x}<52$ & Low \\
\hline 3 & $52 \leq \mathrm{x}<68$ & Medium \\
\hline 4 & $68 \leq \mathrm{x}<84$ & High \\
\hline 5 & $84 \leq \mathrm{x} \leq 100$ & Very High \\
\hline
\end{tabular}

Table 6:- The Frequency of Activity Implementation Scores for Higher-Order Thinking Skills

\begin{tabular}{|c|c|c|c|c|}
\hline Values & Category & \multicolumn{3}{|c|}{ Frequency of Students } \\
\cline { 3 - 5 } & & $\mathrm{A}(\mathrm{N}=21)$ & $\mathrm{B}(\mathrm{N}=28)$ & $\mathrm{C}(\mathrm{N}=30)$ \\
\hline $20 \leq \mathrm{x}<36$ & Very Low & 0 & 0 & 0 \\
\hline $36 \leq \mathrm{x}<52$ & Low & 0 & 0 & 0 \\
\hline $52 \leq \mathrm{x}<68$ & Medium & 0 & 0 & 11 \\
\hline $68 \leq \mathrm{x}<84$ & High & 10 & 10 & 19 \\
\hline $84 \leq \mathrm{x} \leq 100$ & Very High & 11 & $36 \%$ (High) & $37 \%$ (High) \\
\hline \multicolumn{2}{|c|}{ Percentage (\%) } & $48 \%$ (High) & $64 \%$ (Very High) & $63 \%$ (Very High) \\
\hline
\end{tabular}




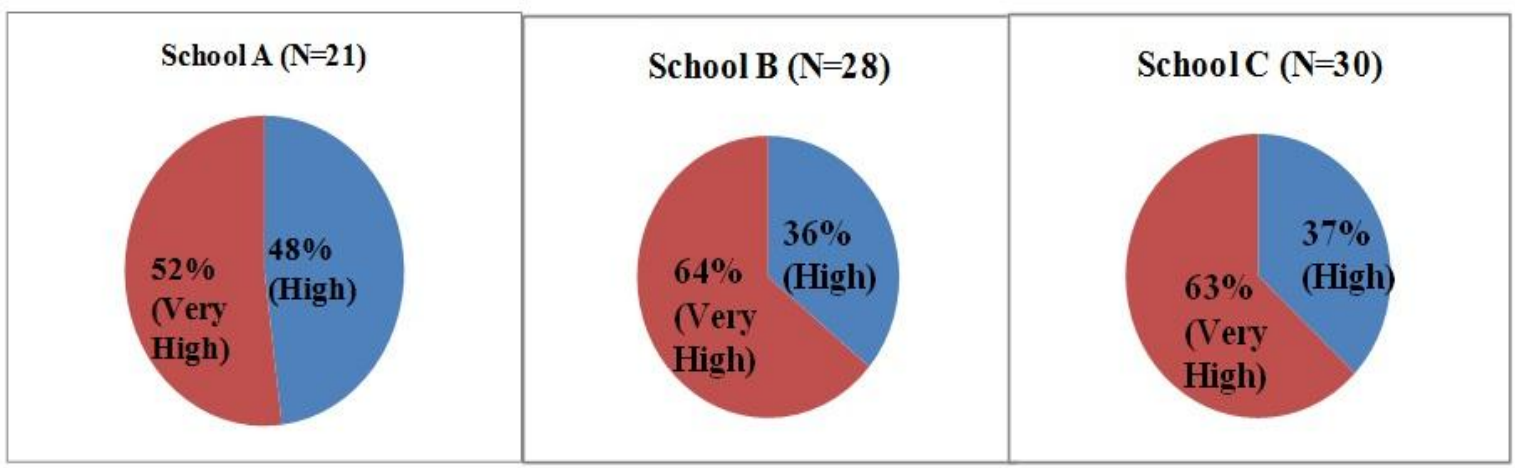

Picture 2:- The Diagram of Percentage Results of Implementation Activity Ability of Higher-Order Thinking Skills

According to Picture 2, it can be seen the percentage of the students' implementation activity of higher-order thinking skills which shows high results in each school with different number of students. At school A is $48 \%$; school B is $36 \%$; and school C is $37 \%$. Based on these results, it shows that the picture-based learning source pack for improving students learning outcomes and higher-order thinking skills are considered in good category with a high percentage of HOTS activity.

\section{Discussion:-}

According to the results of the pretest, posttest, and HOTS tests shown in Tables 3 and 4, it can be interpreted that the students learning outcomes and higher-order thinking skills in schools A, B, and C have improved in each meeting. This proves that the picture-based learning resource pack of the body immunity system material can be used to improve students learning outcomes and higher-order thinking skills. This picture-based learning resource pack of the body immunity system material is complemented by a series of pictures from the beginning to final conditions that include the state of objects, events, or phenomena, where the picture of one with the next picture always contains differences, but differences in pictures are seen as a sequence of conditions previously, so that the picture-based learning source pack becomes an interesting for students and could be used as a learning source that can develop thinking processes that automatically improve student learning outcomes and higher-order thinking skills (Harrow, 1972).

Visualization of concepts related to the process of the immunity mechanism system is the main advantage of this picture-based learning source pack. These advantages are suitable with the characteristics of Biology material expressed by Carin \& Sund (1990), that said Biology material requires the higher-order thinking skills and the elements human, materials, facilities, equipment, and procedures that influence each other to achieve learning objectives. In addition, there are interesting and useful student activities during the learning process by using a picture-based learning source pack. Therefore, the learning source pack which is developed has been considered as very well that can be used in the learning process.

Basically the picture of the process contained in this learning resource package has an attractive appearance and can provide an attraction to students as revealed by Arsyad (2011) that picture media attracts students, can translate abstract ideas in tangible form, shorten a description, clarify the important parts, and easily adapted to the subjects. The existence of this process picture will stimulate students motivation to be happier, enthusiastic, actively ask questions and answer during the learning process (Nieveen, 1999). This picture-based learning source pack becomes an effort to achieve student learning outcomes and support the implementation of meaningful learning activities and also stimulates students higher-order thinking analysis (Kennedy, 2007). According to Krathwohl (2002), students should continue to be pushed to have higher-order thinking skills, so that students can comprehend the material well. Thus, the more active the students are in learning, the more the learning process is maximized, so the possibility of greater comprehension of concepts and learning objectives to improve students learning outcomes and higher-order thinking skills can be achieved. The following is a display of a picture-based learning source on the Body Immunity System material for improving student learning outcomes and higher-order thinking skills. 

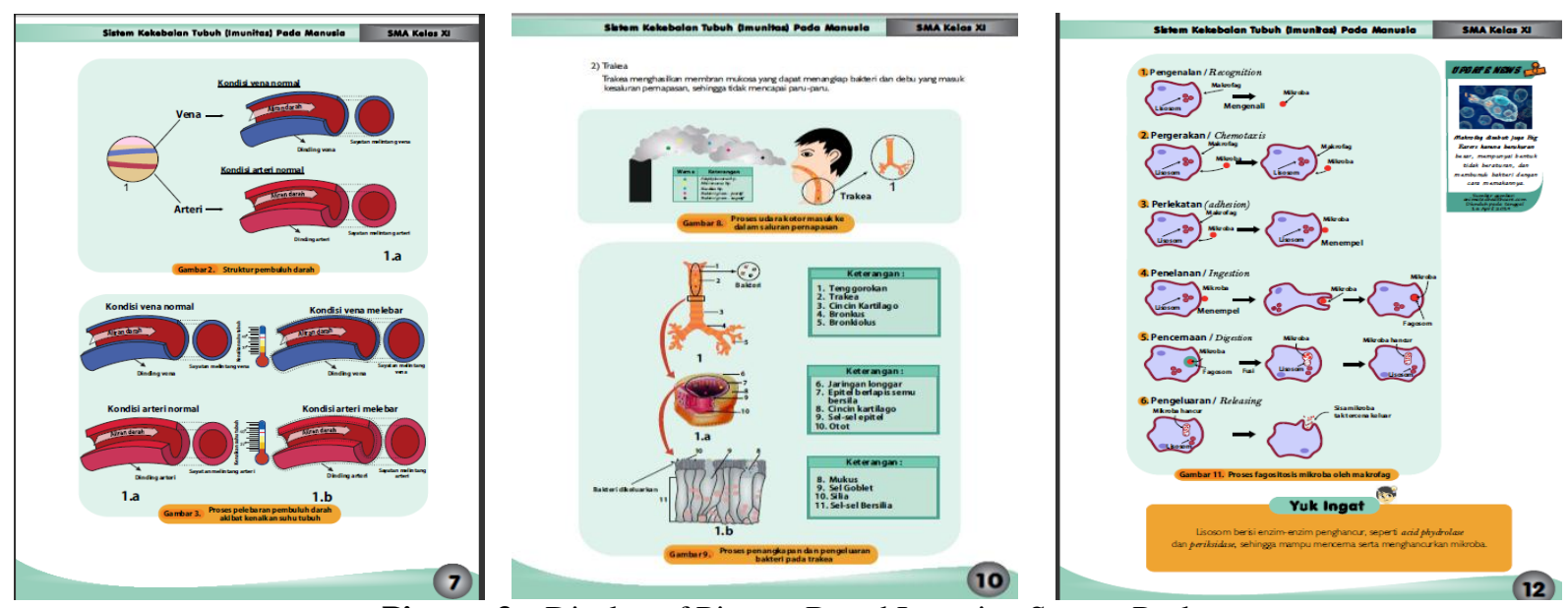

Picture 3:- Display of Picture-Based Learning Source Pack

\section{Conclusion:-}

According to the results and discussion, there is an improvement in the score of students learning outcomes and higher-order thinking skills in each meeting after using a picture-based learning source pack of body immunity system process material in the learning process. In addition, the percentage of students' higher-order thinking skills is also high. So, it can be concluded that the picture-based learning source pack of the body immunity system process material can improve students learning outcomes and higher-order thinking skills. This can be seen from the average scores of (pretest-postest) and higher order thinking skill of the students at the try out (school A, B, and C) that fulfill good category.

\section{References:-}

1. Anderson, G. L., and Neuhouser, M. L. 2012. Obesity and the risk for premenopausal and postmenopausal breast cancer. Cancer Prevention Research. 5(4): 515-521.

2. Anderson, L. W., dan Krathwohl, D. R. 2001. A Taxonomy for Learning, Teaching, and Assesing: A Revision of Bloom's Taxonom y of Educatioanl Objectives. New York: Addison Wesley Longman, In.

3. Arsyad, A. 2011. Media Pembelajaran. Jakarta: PT. Raja Grafindo Persada.

4. Carin, A. A. \& Sund, R. B. 1990. Teaching Science Through Discovery. New York: Merril Publishing Company.

5. Downing, A. et al. 2009. Changes in and predictors of length of stay on hospital after surgery for breast cancer between 1997/98 and 2004/05 in two regions of England: a population-based study. BMC, 9, pp.1-9.

6. Hadiyanti, Lutfia N., dan Widodo, Ari. 2016. Pengembangan Bahan Ajar Materi Sistem Kekebalan Tubuh Manusia Berbasis Pengetahuan Awal Siswa SMA. Jurnal Pembelajaran Biologi. 2(1):39-50.

7. Harrow, A. J. 1972. A taxomy of the psychomotor domain : A guided for developing behavioral objective. New York: David Mc Key Company.

8. Krathwohl, D. R. 2002. A revision of Bloom's taxonomy: An overview. Theory into Practice. 41(4):212-218.

9. Kemendikbud. 2016. Permendikbud Nomor 22 Tahun 2016 Tentang Standar Proses Pendidikan dan Menengah. Jakarta: Kementrian Pendidikan dan Kebudayaan.

10. Kennedy, XJ. 2007. An Introduction to Poetry. Boston: Little Brown and Company.

11. Maisaroh dan Rostrieningsih. 2010. Peningkatan Hasil Belajar Siswa dengan Menggunakan Metode Pembelajaran Active Learning Tipe Quiz Team pada Mata Pelajaran Keterampilan Dasar Komunikasi di SMK Negeri 1 Bogor. Jurnal Ekonomi dan Pendidikan. 8(2):157-172.

12. Morrison, G. R. 2004. Designing Effective Instruction. New York: John Wiley \& Sons, Inc.

13. Nieveen, N. 1999. Prototyping to Reach Product Quality. In Jan van den Akker, Robert Maribe Branch, Kent Gustafson, Nienke Nieveen, Tjeerd Plomp (Eds). Design Upproaches and Tool in Education and Training (page.125-135).

14. Nuroifah, N. \& Bachri, B.S. 2015. Pengembangan Media Pembelajaran Berbasis Android Materi Sistem Ekskresi Siswa Kelas XI SMA Negeri 1 Dawarblandong Mojokerto. Vol.1, No. 1, 3. 
15. Sa'adah, Latifatus D. 2016. Pengembangan Bahan Ajar Handout Berbasis Gambar Materi Kerajaan Islam di Indonesia Untuk Meningkatkan Hasil Belajar Siswa Kelas V Madrasah Ibtidaiyah Negeri Kademangan Blitar. Skripsi. Malang: UIN Maulana Malik Ibrahim Malang.

16. Seels, Barbara B., and Richey, R.C. 1994. Instructional Technology: The Definition and Domains of the Field. Washington, DC: AECT.

17. Shidiq, A. S., Masykuri, M., dan Susanti, V. H. E. 2014. Pengembangan Instrumen Penilaian Two-tier Multiple Choice untuk Mengukur Keterampilan Berpikir Tingkat Tinggi (Higher Order Thinking Skills) pada Materi Kelarutan dan Hasil Kali Kelarutan untuk Siswa SMA/MA Kelas XI. Jurnal Pendidikan Kimia. 3(4):83-92.

18. Sutarto, Indrawati, Prihatin, J., dan Dwi, P.A. 2018. Geometrical Optics Process Image-Based Worksheets for Enhancing Students' Higher-Order Thinking Skills and Self-Regulated Learning. Jurnal Pendidikan IPA Indonesia. 7(4):376-382.

19. Wening, C.J. 2014. Intellectual Process Skillls (within Leves of Inquiry). Artikel Workshop Inkuri.

20. Zaini, Muhammad. 2015. Hasil Belajar dan Keterampilan Berpikir Tingkat Tinggi Siswa SMA Pada Pembelajaran Biologi Menggunakan Model Pembelajaran Berdasarkan Masalah. Jurnal Pendidikan Biologi. Vol. 20:207. 